\title{
Bulletin of the
}

\section{Seismological Society of America}

\section{STRATIGRAPHIC EVIDENCE FOR SEVEN METERS OF DEXTRAL SLIP ON THE SAN ANDREAS FAULT DURING THE 1857 EARTHQUAKE IN THE CARRIZO PLAIN}

\author{
By Lisa B. GRant and KeRRY SieH
}

\begin{abstract}
The smallest geomorphic offsets along a $35 \mathrm{~km}$ section of the San Andreas fault in the Carrizo Plain vary from 7 to $10 \mathrm{~m}$. Our three-dimensional excavation of alluvial deposits a few $\mathrm{km}$ southeast of Wallace Creek confirms that at least 6.6 to $6.9 \mathrm{~m}$ of dextral slip occurred there during the latest large earthquake, in 1857. Dates on detrital charcoal suggest that the last event prior to the 1857 earthquake occurred before a date within the range A.D. 1305 to 1623 . The 3-m range in smallest offsets along this portion of the fault may reflect either a 3-m variation in slip along the San Andreas in 1857, or 2 to $3 \mathrm{~m}$ of slip during an event prior to 1857. Observations made after the recent Landers earthquake are compatible with the hypothesis of large, local variations in slip during a single earthquake, but do not explain the cause of such variations. Off-fault dextral rotations would be one plausible explanation. However, paleoseismic data in the Carrizo Plain are too sparse to allow rejection of the alternative hypothesis that slip in the event prior to 1857 was only 2 to $3 \mathrm{~m}$, an amount of slip which would be several times too small to fit a time-predictable model.
\end{abstract}

\section{INTRODUCTION}

The San Andreas fault has been the primary laboratory in which modern probabilistic seismic hazard analysis has been formulated (Sykes and Nishenko, 1984; Bakun and Lindh, 1985; Wesnousky, 1986; Working Group on California Earthquake Probabilities (WGCEP), 1988). Geological determination of late Holocene slip rates, dates of paleoseismic earthquakes, and geomorphologic estimates of slip per event have been the raw data from which segmentation models have been created, recurrence intervals calculated, and deviations from the average estimated (Bakun and McEvilly, 1984; Schwartz and Coppersmith, 1984; Sykes and Nishenko, 1984; WGCEP, 1988; Sieh et al., 1989; Scholz, 1990). At this time, however, these critical data are sparse and thus, models of fault behavior are still primitive.

In this paper, we attempt to improve the quality of one piece of data: the amount of dextral slip that occurred in the Carrizo Plain during the great 1857 earthquake. Sieh and Jahns (1984) reported that dextral offsets of ephemeral stream channels cluster around 10,22, and $33 \mathrm{~m}$ near Wallace Creek. Thus, they interpreted the latest three earthquakes along this section of the San Andreas fault to have produced about 10,12 , and $11 \mathrm{~m}$ of slip, respectively. That interpretation, coupled with an estimated $34 \pm 3 \mathrm{~mm} / \mathrm{yr}$ rate of late Holocene slip at Wallace Creek, was their basis for estimating the recurrence 
interval at between 240 to 450 years along this section of the San Andreas. These observations and interpretations have now been used in estimates of long-term earthquake probabilities (Sykes and Nishenko, 1984; Wesnousky, 1986; WGCEP, 1988), mechanical models of fault behavior (Schwartz and Coppersmith, 1984; Stuart, 1986; Rundle, 1988; Huang and Turcotte, 1990), and in rupture correlation models (Sieh and Jahns, 1984; Sieh et al., 1989).

Despite the widespread use of the interpretation, little attention has been paid either to the uncertainties in the interpretation of offset geomorphic features, or the effects of these uncertainties on current fault models and estimates of hazard. Such an assessment is important to seismic hazard analysis and our understanding of fault mechanics. For example, if seismic offsets in the Carrizo Plain are typically about $10 \mathrm{~m}$, then recurrence intervals must average about 300 years, more than twice the current 136-year interval of dormancy. This implies very low probabilities for repetition of the 1857 earthquake in the near future (Fig. 1). Alternatively, if slip is typically less than $10 \mathrm{~m}$ during Carrizo Plain earthquakes, then the San Andreas may be much closer to failure than previously considered. Finally, the recurrence characteristics of large earthquakes within the Carrizo Plain must be explained by any fault model designed to describe the mechanical behavior of the fault.

Here we attempt to evaluate the reliability of the geomorphic data, using stratigraphic information. Without historic measurements or stratigraphic control on the number of events per offset, it is very difficult to determine how many earthquakes formed each geomorphic offset and how much slip occurs per earthquake.

Our first suspicion that the 9.5-m offsets documented by Sieh (1978) were not completely representative of offsets in the Carrizo Plain arose when we found several dextral offsets that were closer to $7 \mathrm{~m}$ in value. Two of these are shown in Figures 2 and 3. Other measurements by Sieh (1978) include three additional sites along the same stretch of the fault with substantially less than $9.5 \mathrm{~m}$ of offset. Were these representative of slip in 1857 ? If so, could the $9.5 \mathrm{~m}$ offsets represent the 1857 earthquake plus an earlier, smaller offset?

To address this uncertainty, we excavated in three dimensions an active alluvial fan at its intersection with the San Andreas fault at the Phelan Ranch to obtain stratigraphic evidence of the amount of slip which occurred in the most recent, or 1857 Fort Tejon, earthquake and its predecessor.

\section{STTE DESCRIPTION}

The Phelan fan site is on the San Andreas fault in the Carrizo Plain $2.6 \mathrm{~km}$ southeast of Wallace Creek (Fig. 1). At the site, a stream channel that extends upstream to the crest of the Temblor Range debouches onto an alluvial fan, the apex of which buries the fault (Fig. 4). Northeast of the fault is a 10- to 15-m-high scarp underlain by dissected late Pleistocene alluvial fan deposits. Southwest of the fault are deposits of the alluvial fan and colluvial slope deposits.

The Phelan fan has two geomorphically mappable lobes, Qf1 and Qf2 (Fig. 4). The active fan channel, nearly filled with alluvium (labelled Qa1), supplies sediment to the southeastern lobe of the fan, Qf1. The Qf2 lobe of the fan, northwest of the active channel, is topographically higher than the Qf1 lobe, suggesting that it was constructed principally prior to 1857 and offset to the northwest during the 1857 earthquake. This was confirmed by excavations. 


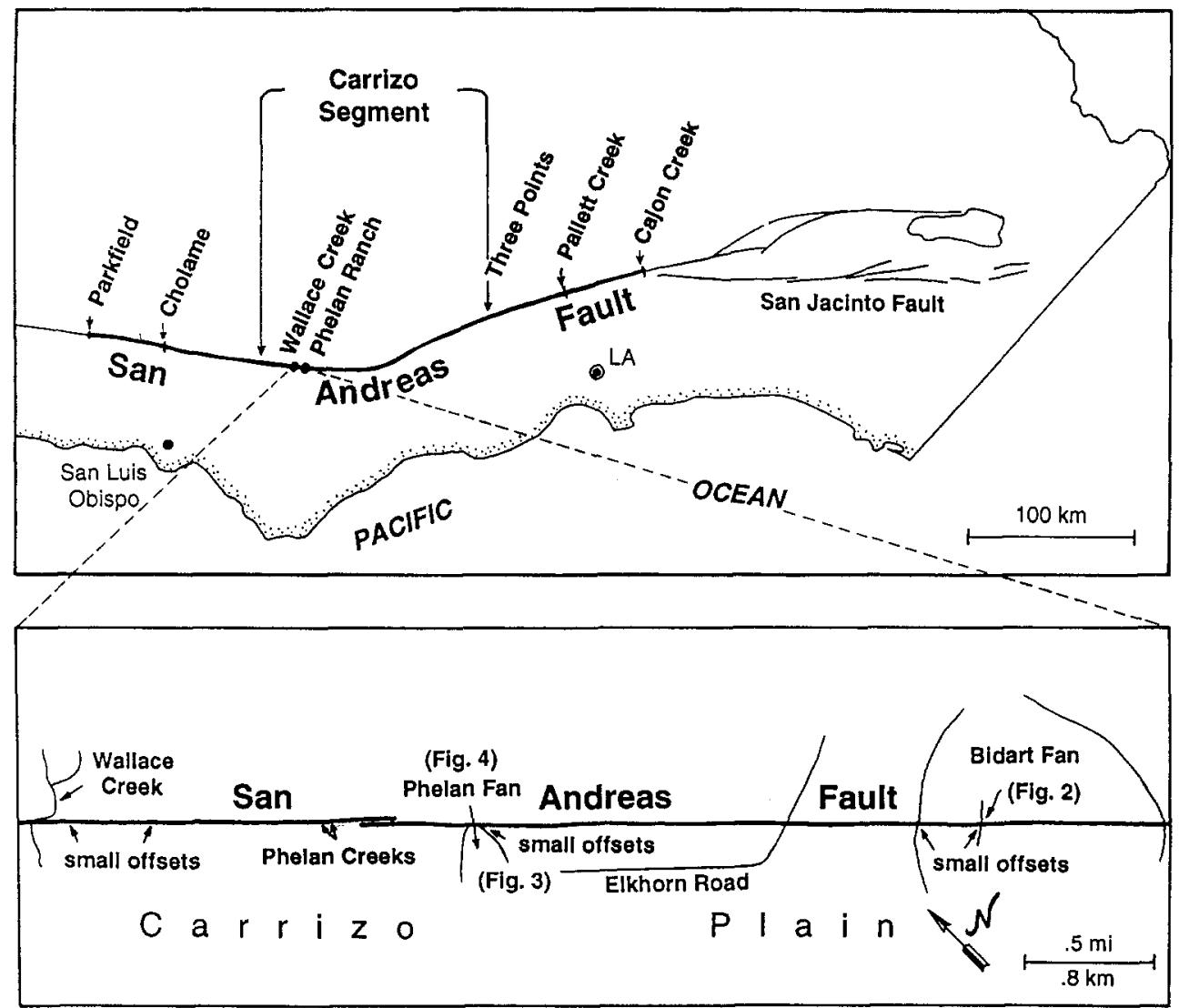

Fig. 1. The San Andreas fault in southern California last ruptured in 1857, along a 350 to 400 $\mathrm{km}$ stretch from Parkfield to near Cajon Creek. Wallace Creek and the Phelan fan site are located along the Carrizo segment of the San Andreas in the northwestern Carrizo Plain. Numerous small offsets are well preserved in the northern half of the Carrizo fault segment. The Carrizo segment of the fault sustained at least $6 \mathrm{~m}$ of slip during the 1857 earthquake. In this paper, we discuss 7- to $10-\mathrm{m}$ geomorphic offsets along the $35 \mathrm{~km}$ portion of the San Andreas fault that extends approximately $25 \mathrm{~km}$ southeast and $10 \mathrm{~km}$ northwest of Wallace Creek. Modified from Sieh et al., 1989.

\section{EXCAVATION}

We excavated five trenches parallel and perpendicular to the fault to determine the precise location of the fault zone, and to identify stratigraphic features that are offset by the fault to use as piercing lines for measuring slip. We cleaned off, surveyed, and mapped the trench walls in detail, at a scale of 1:20.

After describing, mapping, and correlating units in the trenches, we chose a piercing line for detailed 3-D excavation. Beginning at the walls of trenches 3 and 4 , and moving toward the fault, we excavated the entire length of the piercing line by hand and cleaned it off with brushes. We then dug out the piercing line past trenches 3 and 4, moving away from the fault zone. We placed nails approximately every 10 to $20 \mathrm{~cm}$ along the top of the exposed piercing line, and surveyed the nail locations using a Wild TC2000 Total Station. When we encountered small faults and the main fault zone, we nailed and surveyed them in the same manner. We also excavated the Qa1 alluvium of the active channel between trenches 3 and 4 and found that the sedimentary fill was not broken by any faults. 


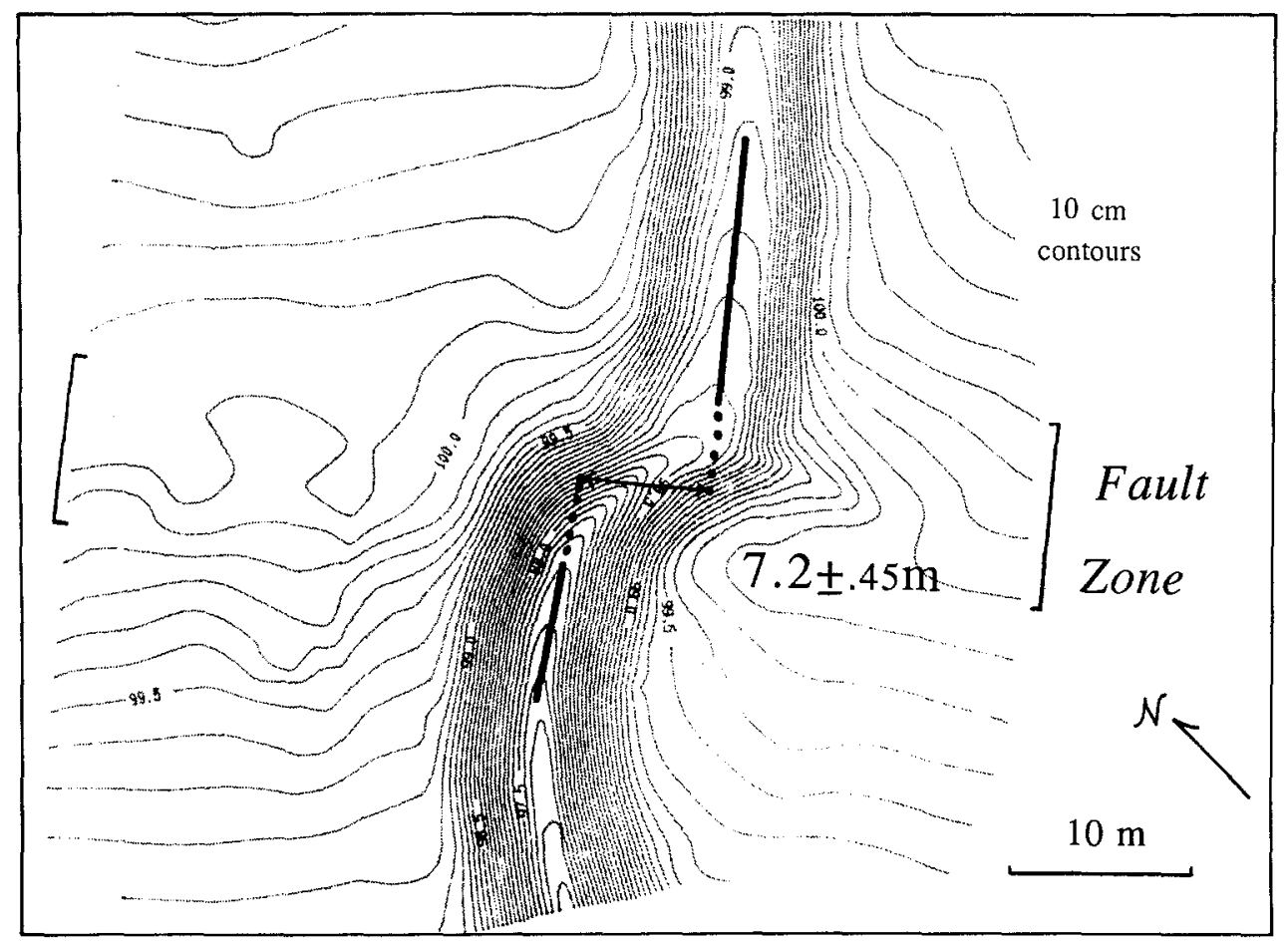

Fig. 2. Contour map (0.1-m contour interval) of an incised ephemeral stream channel on the Bidart Ranch alluvial fan $5.6 \mathrm{~km}$ southeast of Wallace Creek and $3.0 \mathrm{~km}$ southeast of the Phelan fan excavation site. The San Andreas fault extends between brackets. The channel is offset about $7.2 \mathrm{~m}$ in a right-lateral sense across the fault. The offset is measured by projecting the parallel trends of the channel (thick lines) to the middle of the fault zone from just outside the fault zone. Elevation datum in this and other figures is arbitrary.

\section{STRATIGRAPHY}

The trenches revealed several buried fanhead channels and the subsurface expression of the active fanhead channel, Qa1. The channels exposed in the trench walls were visually prominent features with sharp contacts. Distinctive coarse sand and gravel deposits with imbricated clasts, scour and fill structures, and sparse matrix filled the scoured channels. In the upper levels of each channel, up to the surface of the alluvial fan, debris flows and gravel deposits interfingered and spread out laterally above the elevation of the channel banks, producing the surficial fan morphology.

Three fanhead channels $\left(\mathrm{A}^{\prime}, \mathrm{B}^{\prime}, \mathrm{C}^{\prime}\right)$ existed in trenches 1 and 3 , on the downstream (southwest) side of the fault. These are labeled $\mathrm{A}^{\prime}, \mathrm{B}^{\prime}$, and $\mathrm{C}^{\prime}$ in Figures 5 and 6 . Two channels labeled $\mathrm{A}-\mathrm{B}$ and $\mathrm{C}$, existed in trench 4 , on the upstream (northeast) side of the fault. In trench 3 , channels $\mathrm{A}^{\prime}, \mathrm{B}^{\prime}$, and $\mathrm{C}^{\prime}$ cut poorly sorted, poorly indurated, colluvial slope wash deposits (Qc) that display no bedding or other sedimentary structures. We hypothesize that these deposits were shed off the 10 to $15 \mathrm{~m}$ scarp to the southeast of the alluvial fan apex, and transported northwest by faulting, prior to channel incision.

Upstream from the fault, in trench 4, channel A-B cut indurated, well-bedded siltstone, mudstone, and sandstone (Qpf) which we interpret as the mid-to-distal facies of deposits of much older alluvial fan beds (Table 1). The southeastern margin of channel $\mathrm{C}$ also cut the same lithified beds. The base and northwestern margin of channel $\mathrm{C}$ cut burrowed, layered, and channelized beds of gravel 


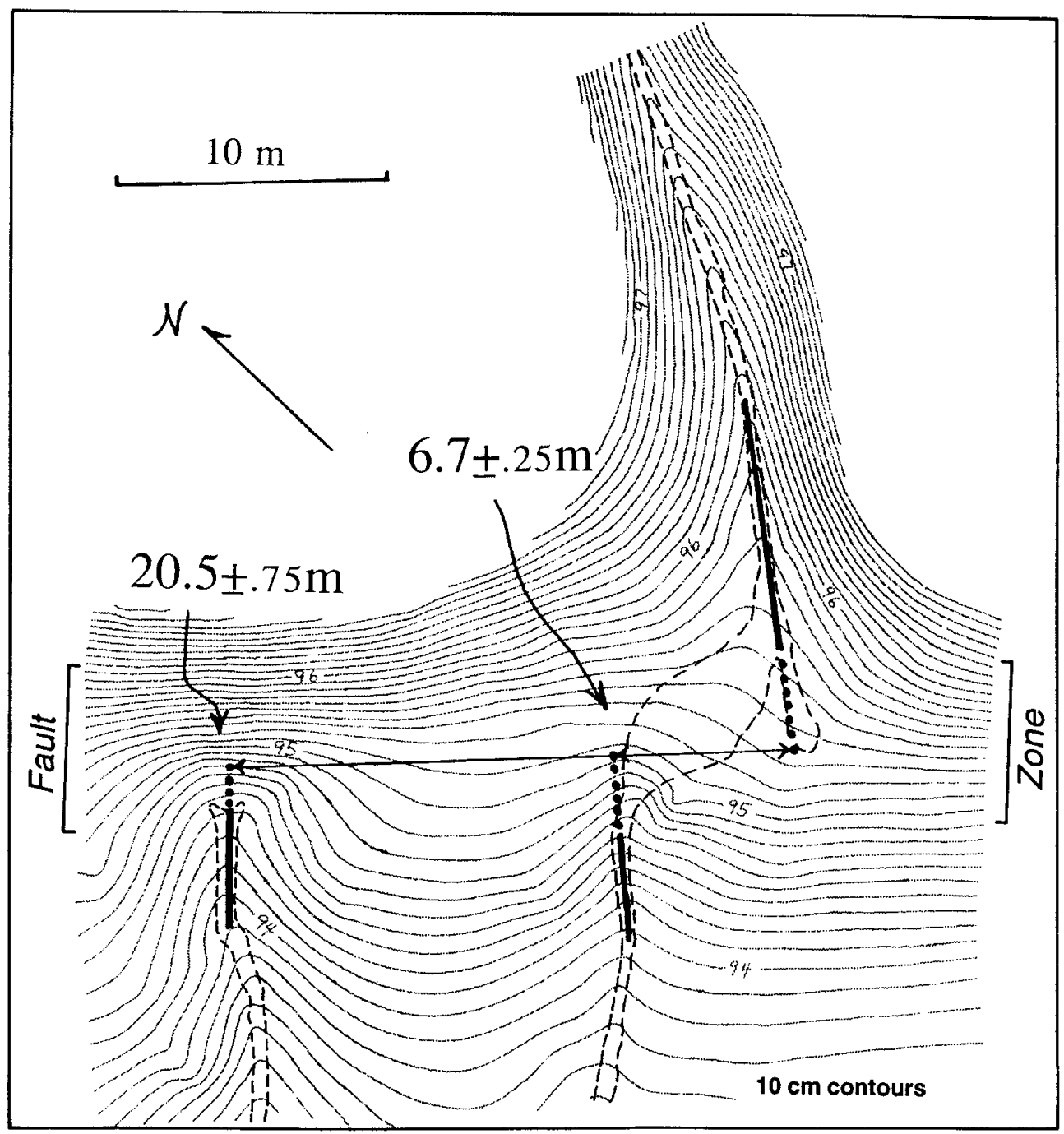

Fig. 3. Contour map (0.1-m contour interval) of two stream gullies $0.1 \mathrm{~km}$ southeast of the Phelan fan excavation site. The San Andreas fault extends between the brackets. The channels are dextrally offset across the fault approximately 6.7 and $20.5 \mathrm{~m}$. Offset is measured by projecting the trend of each gully (thick lines) to the fault zone.

and debris flows. These beds are correlated with terrace Qa2 because they underlie the surface of this terrace (Fig. 4). The upper contact of the Qa2 deposits in trench 4 (Fig. 6) is irregular due to the presence of burrows. In trenches 4 and 5, unit Qa2 grades upward into bioturbated colluvium.

A baked, reddish black, fire scar formed an important time-stratigraphic marker in the upper sediments of channels $\mathrm{C}$ and $\mathrm{C}^{\prime}$. In gravel beds, the fire scar was a red and black rind around pebble clasts. At the surface of debris flow beds, it was a reddish horizon. Charcoal clasts were locally abundant within the burned horizon and, in one place, were entrained in the base of a debris flow bed on top of the fire scar. Due to its patchy areal extent, the fire scar was not observed in the walls of trenches 3 and 4 . It was well developed in the sediments between the trenches, in the beds just above the piercing line. 


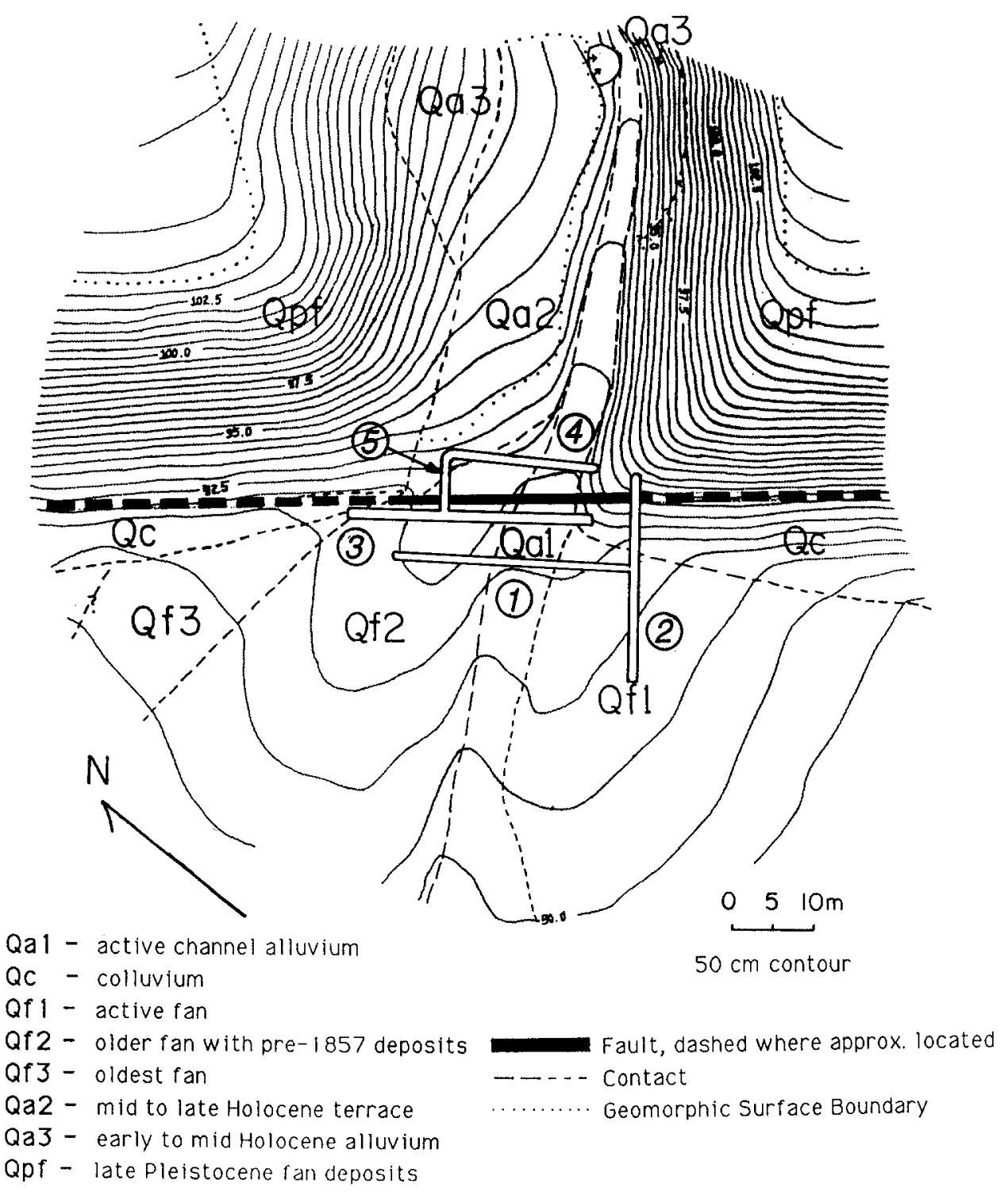

FIG. 4. Contour map (0.5-m contour interval) of an alluvial fan on the Phelan Ranch $2.6 \mathrm{~km}$ southeast of Wallace Creek. Stream channel alluvium (Qa1) crosses the San Andreas fault. Indurated late Pleistocene siltstone and sandstone beds (Qpf) are in fault contact with Recent alluvial fan deposits (Qf1, Qf2). A blanket of colluvial slope wash (Qc) lies at the base of a scarp. Fluvial terraces are mapped as Qa2 and Qa3. Locations of five trenches (numbered) are shown.

\section{Correlation of Channels}

Excavation of the Qa1 deposits between trenches 3 and 4 demonstrated that the sedimentary fill of channel $\mathrm{A}-\mathrm{B}$ in trench 4 is continuous with the fill of channel $A^{\prime}$ in trench 3 (Fig. 6). Both the upstream and downstream parts of active channel $A-B, A^{\prime}$ therefore, formed and filled after the last major earthquake. Channel $\mathrm{B}^{\prime}$ is inferred to have been fed by source channel $A-B$, and then offset by the San Andreas fault (Fig. 5). Because channel A-B now contains the younger, unfaulted Qa1 sediments, individual beds cannot be matched between 


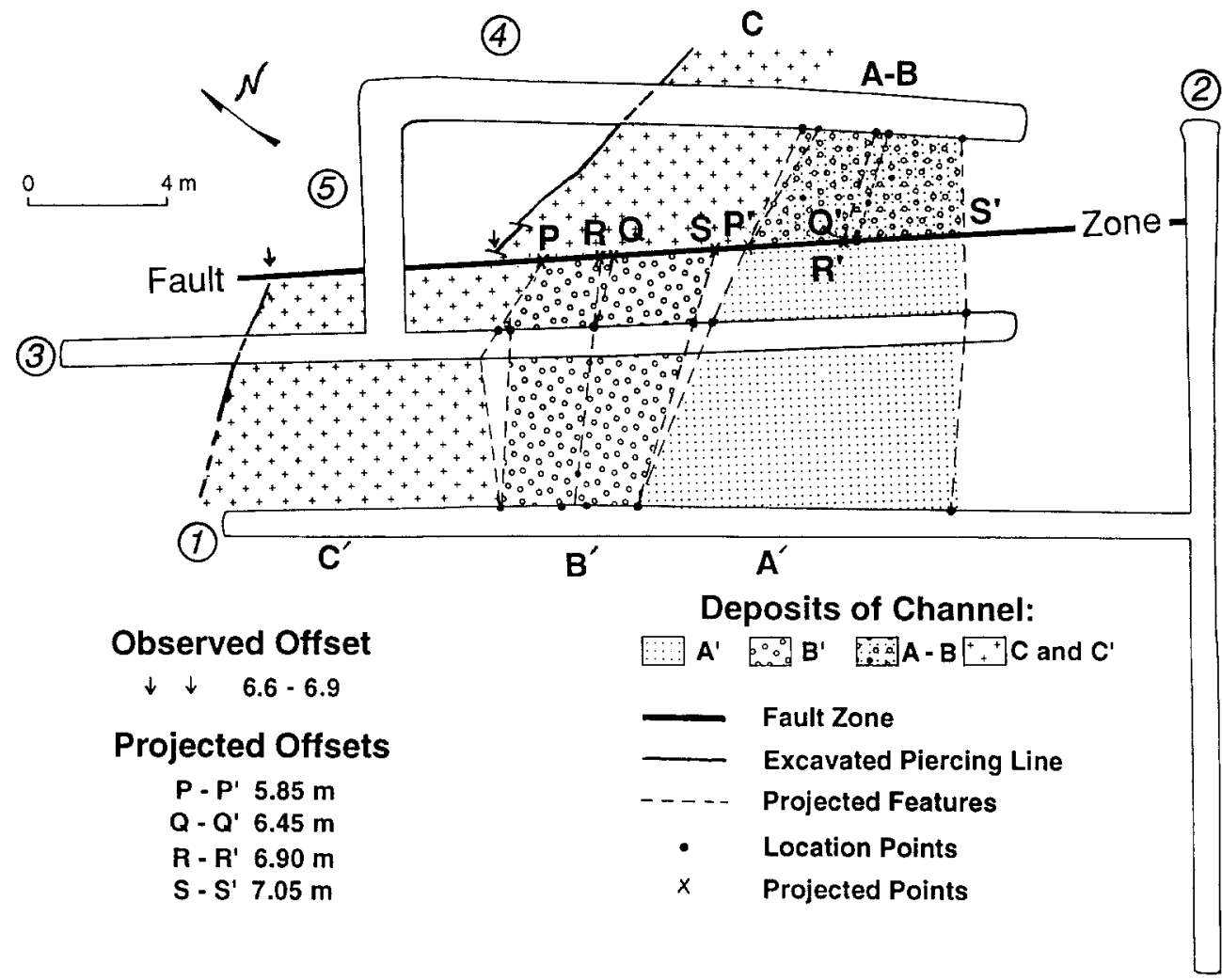

FIG. 5. A plan view of the channels and fault zone was constructed from their exposure in the trench walls, locations from 3-D excavations, and projections of stratigraphic features. Channels $\mathbf{B}^{\prime}$ (circles) and $\mathrm{C}^{\prime}$ (crosses) are offset from the sources. Channel $\mathrm{A}^{\prime}$ (dots) extends across the fault to its source, channel A-B (circles and dots). The channel bank piercing line at the northern margin of offset channels $\mathrm{C}$ and $\mathrm{C}^{\prime}$ was exposed by excavation. Bold dots mark the endpoints of piercing lines (dashed) projected beyond the trench walls. Projected Offsets ( $\mathbf{P}-\mathbf{P}^{\prime}$, etc.) are inferred from projection of piercing lines to the fault. $P$ and $P^{\prime}$ are the projected locations of the southern bank of channel $\mathrm{C}-\mathrm{C}^{\prime}$, at the fault zone. $\mathrm{S}-\mathrm{S}^{\prime}$ is the estimated offset of the southern bank of channel $\mathrm{B}-\mathrm{B}^{\prime}$. Lines $Q-Q^{\prime}$ and $R-R^{\prime}$ are different projections of the thalweg of the channel $B-B^{\prime}$. The Observed Offset was determined by excavating the piercing line to the fault (arrows). Numbered circles refer to trench numbers.

channel $\mathrm{B}^{\prime}$ and channel A-B to prove the correlation hypothesis. However, no other plausible hypothesis exists.

We interpret the sizes, locations, stratigraphic positions, sedimentary structures, and individual beds of channels $C$ and $C^{\prime}$ displayed in trenches 1,3 , and 4 to suggest that they correlate across the San Andreas fault and are offset (Figs. 5,6 , and 8 ). This correlation was confirmed during the piercing line excavation.

\section{MEASUREMENT OF OFFSET}

The amount and sense of offset of channels $\mathrm{B}^{\prime}$ and $\mathrm{C}^{\prime}$ west of the fault can be estimated from projections of several piercing lines (Fig. 5). The estimates range from $5.85 \mathrm{~m}$ to $7.05 \mathrm{~m}$, depending on the piercing line projection used. The projections of individual piercing lines differ between different trenches, so offset estimates vary. To measure the offset accurately, it is necessary to trace a single piercing line to the point where it intersects each side of the fault. 


\section{Stratigraphy of Trenches 3 and 4}

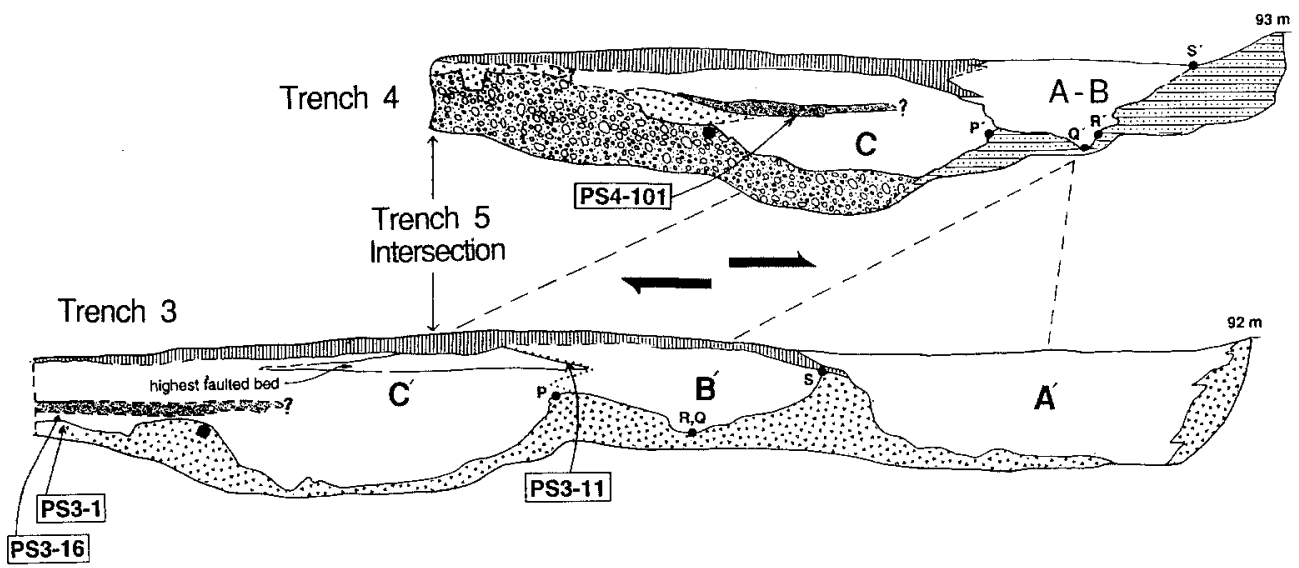

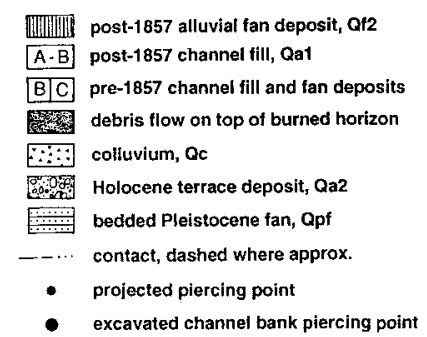

Looking NE

Fig. 6. Cross-sectional map of generalized stratigraphy of trenches 3 and 4 reveals a set of three fanhead channels. Channels $B^{\prime}$ and $C^{\prime}$ have been offset from channels $A-B$ and $C$, respectively. Channel A-B, $A^{\prime}$ is the currently active channel. The location of the excavated channel bank piercing line is marked with a large dot on the northwest bank of channel $\mathrm{C}-\mathrm{C}^{\prime}$. A fire scar is prominent in the sediments between trenches 3 and 4 , but does not crop out in either of the trench walls. A laterally extensive debris flow bed deposited on top of the burned horizon and correlated between the trenches is shown with dark stipple. Locations of piercing line projections from Figure 5 are marked with corresponding letters. Radiocarbon samples PS3-1, PS3-11, and PS3-16 were collected from the locations shown. Sample PS4-101 was collected from the fire scar between trenches 3 and 4 , at the horizon shown. Sample PS2-3 was collected from unit Qpf, in trench 2 (not shown). Detailed lithologic logs of all five trenches may be obtained from the first author, L. Grant.

We examined channels $\mathrm{C}$ and $\mathrm{C}^{\prime}$ for features that were identifiable on both sides of the fault, to use as a piercing line. We chose the intersection of the top of the northwestern channel bank with overlying debris flows and gravel lenses, on each side of the fault as the piercing line. We excavated and surveyed the top of the channel bank. Figure 7a is a map view of the piercing line and the faults that cut it. The channel bank has an irregular shape, as expected for a natural fluvial feature, and is slightly disrupted by small faults outside the main fault zone. On the west side of the fault, the piercing line intercepts the main fault zone at point $\mathrm{W}$. Two small faults with less than a centimeter of displacement each cut the piercing line between $\mathrm{W}$ and trench 3 . No faults were observed west of trench 3, although some minor faults might have been removed by excavation of trench 3 . If we project the piercing line toward the fault, from the unfaulted region west of trench 3 , it intersects the fault zone at $Z$.

Two left-lateral faults on the northeastern side of the fault zone have rotated a block containing part of the piercing line clockwise. If slip is restored on these small faults, the piercing line intersects the main fault zone at $\mathrm{X}^{\prime}$. The piercing line can also be projected to the main fault from the closest unfaulted region, to 
TABLE 1

RADIOCARBON ANALYSES

\begin{tabular}{|c|c|c|c|c|c|}
\hline \multirow[t]{2}{*}{$\begin{array}{c}\text { Sample ID } \\
\text { Caltech/Lab }\end{array}$} & \multirow{2}{*}{$\delta^{13} \mathrm{C}$} & \multirow{2}{*}{ Unit } & \multirow{2}{*}{$\begin{array}{c}\text { Conventional } \\
\text { Radiocarbon Age } \\
\text { (years B.P. at } 1 \sigma \text { ) }\end{array}$} & \multicolumn{2}{|c|}{$\begin{array}{l}\text { Dendro-Corrected Age } \\
\text { (calendar years A.D.) }\end{array}$} \\
\hline & & & & $1 \sigma$ & $2 \sigma$ \\
\hline PS2-3/AA5075* & $-25^{\dagger}$ & $\begin{array}{l}\text { Qpf } \\
\text { trench } 2\end{array}$ & $13,860 \pm 100$ & - & - \\
\hline PS3-1/AA5072* & $\begin{array}{l}-12^{\dagger} \\
-25^{\dagger}\end{array}$ & colluvium & $\begin{array}{l}476 \pm 60 \\
370 \pm 60\end{array}$ & $\begin{array}{l}1332-1472 \\
1450-1630\end{array}$ & $\begin{array}{l}1305-1623 \\
1440-1640\end{array}$ \\
\hline PS3-11/AA5073* & -11 & debris flow & $138 \pm 32$ & $1681-1936$ & $1670-1947$ \\
\hline PS3-16/AA5074* & -21 & gravel & $535 \pm 40$ & $1320-1430$ & $1300-1440$ \\
\hline PS4-101/QL-4470 & -13.3 & fire scar & $1016 \pm 19$ & $987-1023$ & $901-1151$ \\
\hline $\mathrm{PS} 4-101 \mathrm{t} / \mathrm{TO}-2564^{\S}$ & not reported & fire scar & $600 \pm 50$ & $1298-1406$ & $1263-1438$ \\
\hline
\end{tabular}

* The samples were dates at the NSF Accelerator Facility at the Univ. of Arizona and were partially funded by NSF grant EAR85-12761. Results are quoted from D. Donahue and T. Jull, and include an unspecified error multiplier.

${ }^{\dagger}$ Assummed value. Not measured due to insufficient sample size. Calendar age from method B of Stuiver and Reimer (1986), with no additional error multiplier.

${ }^{\ddagger}$ Measurements quoted from M. Stuiver at Univ. of Washington, Quaternary Isotope Lab. Calendar age from method B of Stuiver and Reimer (1986), with 1.6 error multiplier.

${ }^{\S}$ Measurement from R. P. Beukens, IsoTrace Radiocarbon Lab, Univ. of Toronto. Calendar age from method B of Stuiver and Reimer (1986) with 1.6 error multiplier.

intersect at point X. If we project from beyond trench 4 , to account for any faults destroyed by trench 4 , the intersection point is $\mathrm{Y}$.

The offsets measured from these points vary between $5.85 \mathrm{~m}$ and $7.15 \mathrm{~m}$. To determine the most plausible value, we restore the slip on the major and minor faults and examine the match in trends of the lines on either side of the fault. The best fits (Figure $7 \mathrm{~b}$ ) are at points $\mathrm{W}-\mathrm{X}^{\prime}$ and $\mathrm{Z}-\mathrm{X}^{\prime}$. In both restorations, the trends of the channel bank on either side of the main fault zone match well. The possibility that additional dextral slip is hidden as warping within the aperture of our excavation is impossible to evaluate conclusively. The arcuate nature of the piercing line suggests the possibility of additional dextral warp, but the coarse nature of the sediments precluded paleomagnetic sampling such as that utilized by Salyards et al. (1992) and Nagy and Sieh (1993). Alternatively, the bend in the channel could be nontectonic. The paucity of secondary faults within the excavations suggests the bend is not tectonic. Therefore, we conclude that the piercing line was offset 6.6 to $6.9 \mathrm{~m}$ by the San Andreas fault.

\section{Number of FAULTiNg EventS}

Trenches 2 and 5 lie approximately perpendicular to the San Andreas fault (Fig. 4) and display clear evidence of recent faulting. In trench 2 , the faults extend through colluvium to within centimeters of the surface, where details are obscured by bioturbation (data not shown). In trench 5 , the main fault zone juxtaposes colluvium, bioturbated beds, and beds correlated with terrace Qa2, against the gravels that fill and overtop channel $\mathrm{C}^{\prime}$ (Fig. 8). A veneer of alluvial fan debris flows covers the faulted units. The highest faults in trench 5 extend upward to the same stratigraphic level as the faults observed in the uppermost channel $\mathrm{C}^{\prime}$ gravels of trench 3 . Thus, the sediments of channel $\mathrm{C}^{\prime}$ were dextrally faulted away from their source and juxtaposed against terrace and colluvial deposits. 


\section{a Piercing Line offset}

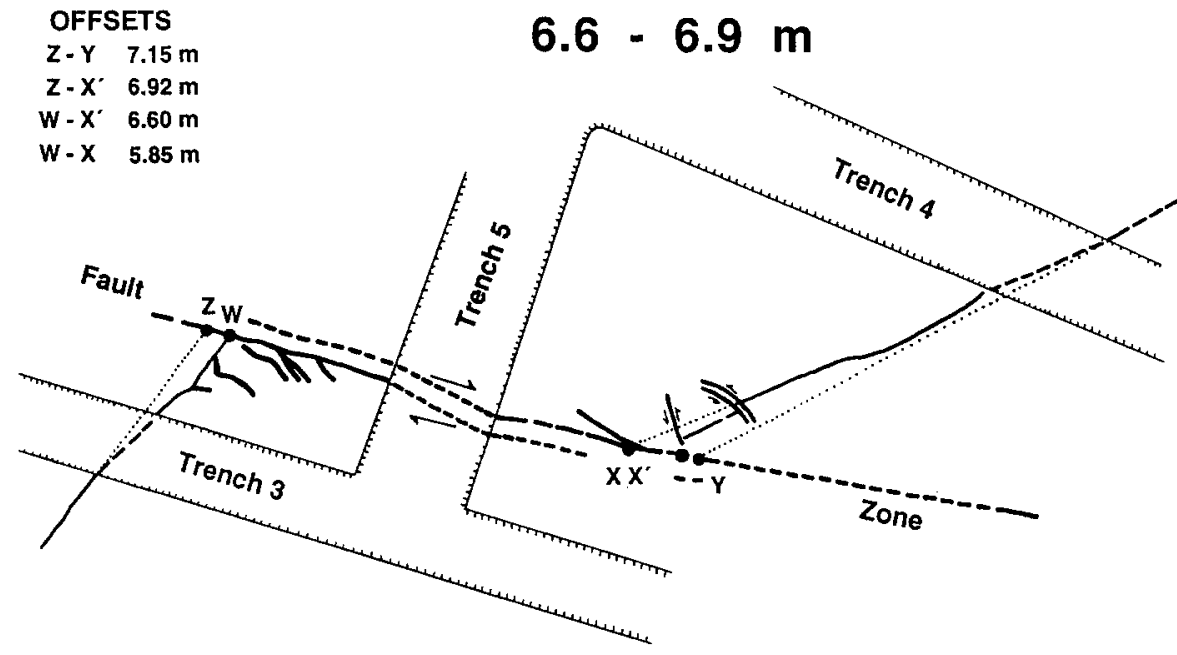

b Slip Restoration
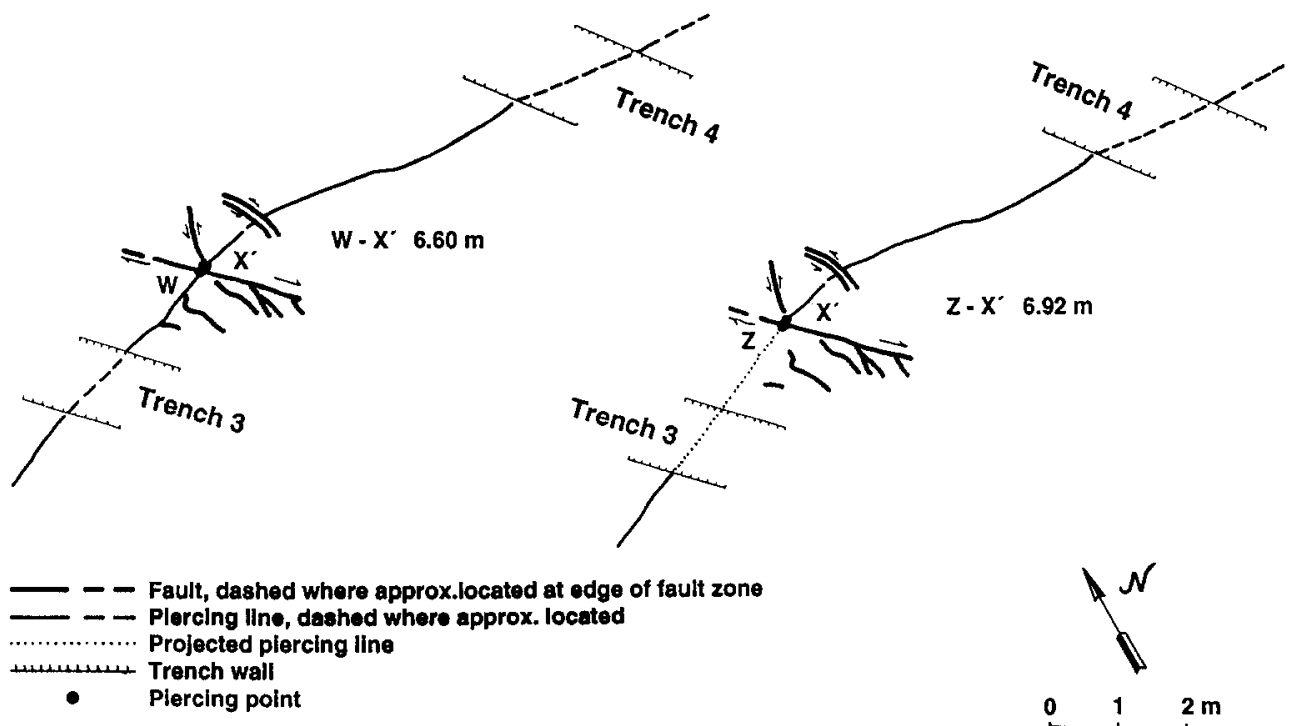

FIG. 7. (a) The excavated top of the northern bank of channel $\mathrm{C}^{-\mathrm{C}^{\prime}}$ forms a piercing line which was surveyed to measure offset. Maximum offset is obtained by projecting the piercing line to the fault zone from beyond trenches 3 and 4 to points $\mathrm{Z}$ and $\mathrm{Y}$. Point $\mathrm{W}$ is at the intersection of the piercing line and the main fault zone. Point $\mathrm{X}$ is projected to the main fault from just outside the maximum observed width of the fault zone. Point $\mathrm{X}^{\prime}$ is the best estimate of the intersection of the piercing line and the main fault zone, after restoration of slip on the smaller faults (See text.). (b) Restoration of slip along the faults reveals the best match in trends of the piercing lines at $W^{\prime}$ and $\mathrm{ZX}^{\prime}$, indicating 6.6 to $6.9 \mathrm{~m}$ of offset. 


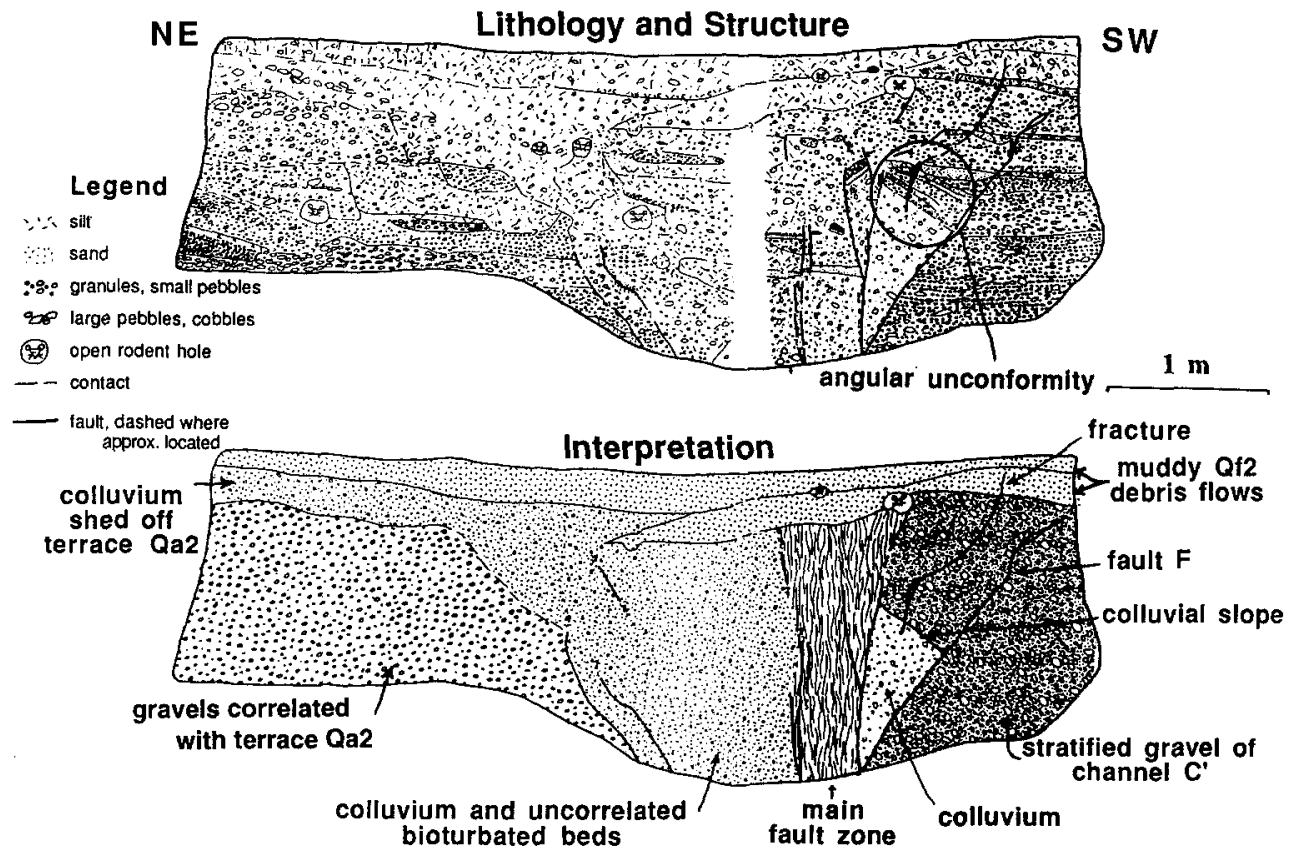

FIG. 8. Lithologic (top) and interpretive (bottom) logs of trench 5. The trench was approximately perpendicular to the fault zone. Legend shows meaning of symbols in the upper log. A circle encloses the angular unconformity on the upper log. Units and important structures in the interpretive log are marked with labels and generalized symbols. Observer is facing southeast.

One of the near surface debris flows which covers the fault zone in trench 5 contains a fracture extending upward from one of the fault traces (Fig. 8). No displacement is observed across the fracture, and it terminates before reaching the top of the bed. Therefore, we interpret that it formed as a result of a small amount of aftercreep, settling or dessication, rather than by seismic faulting. There are no faults in the same debris flow along the wall of trench 3 , or in the debris flow above it.

Several faults within the colluvium terminate below the ground surface and could be from older events. However, the colluvium is heavily bioturbated and thus the upward terminations of the fault traces are unreliable indicators of the stratigraphic level of faulting.

Evidence for the number of faulting events which offset channel $\mathrm{C}^{\prime}$ from channel $\mathrm{C}$ is ambiguous. Facies changes across one of the faults and an angular unconformity suggest multiple events. In trench 5, southwest of the main shear zone, a sequence of apparently dipping beds is capped by nearly horizontal beds (Fig. 8, circle). This sequence can be interpreted as an angular unconformity caused by faulting. If so, it would suggest that channel $\mathrm{C}-\mathrm{C}^{\prime}$ was offset by at least two earthquakes. However, the same sequence of beds on the other wall of trench 5 does not show an angular unconformity. Below the angular unconformity, a wedge of unstratified sand and gravel, interpreted as colluvium, is faulted against stratified gravels of channel $\mathrm{C}^{\prime}$, forming an apparent facies change across the lower reach of fault $F$ (Fig. 8). The sequence of beds on either side of the upper reach of fault $\mathrm{F}$ is similar. One interpretation is that the lower reach of fault $\mathbf{F}$ slipped in multiple earthquakes, and the upper part formed and 
slipped only during the last earthquake, resulting in less offset along the upper reach of the fault.

A single earthquake interpretation is that slip on fault $F$ during the most recent earthquake juxtaposed different facies of channel $\mathrm{C}-\mathrm{C}^{\prime}$. In this interpretation, the dipping beds (Fig. 8, circle) were deposited on a sloping wedge of colluvium. At the ground surface (Fig. 4), the deposits of fan Qf2 lap against the southwest-sloping edge of terrace Qa2. The edge of terrace Qa2 is shedding colluvium. Colluvium is also shed off the southwest slop of the Qpf scarp (Fig. 4). The beds in the angular unconformity (Fig. 8) appear to dip to the southwest. The dipping beds in trench 5 were probably deposited against a colluvial slope at the margins of channel $\mathrm{C}-\mathrm{C}^{\prime}$, and then faulted into contact with stratified gravels from inner channel $\mathrm{C}^{\prime}$. We favor this interpretation because it is consistent with the geomorphology at the site. Thus, although we cannot rule out the existence of more than one event, our favored interpretation is that a single, large earthquake offset channel $\mathrm{C}^{\prime} 6.6$ to $6.9 \mathrm{~m}$ from channel $\mathrm{C}$.

\section{DATING OF UNITS AND FAULTING}

Abundant tiny fragments of detrital charcoal were embedded in debris flows, sandy gravels, colluvium, and in the lithified sediments of unit Qpf. A small percentage of the samples were large enough ( $>10 \mathrm{mg}$ of carbon) to be dated by accelerator mass spectrometry (AMS). Some of the samples were too small to measure the $\delta^{13} \mathrm{C}$ ratio, complicating the interpretation of their radiocarbon ages.

A further complication results from the detrital nature of the samples and from the presence of long-lived plant species in the area. These problems, and our interpretations of the radiocarbon dates, are discussed below and summarized in Table 1. Dendro-calibrated calendric age ranges are discussed at the $2 \sigma$ rather than $1 \sigma$ level because it reduces the likelihood of error in our interpretations.

Charcoal sample PS3-11 was collected from the highest faulted bed above channels $\mathrm{C}^{\prime}$ and $\mathrm{B}^{\prime}$ (Fig. 6). The reported $2 \sigma$ calendar age range of sample PS3-11 is A.D. 1670 to 1947 . Hence, offset of $C^{\prime}$ and $B^{\prime}$ postdates A.D. 1670 to 1947. Because A.D. 1857 falls within the age range A.D. 1640 to 1947 , the stratigraphy indicates that the immediately subjacent channel sediments were offset by the most recent large earthquake, and history records that the most recent large earthquake on the San Andreas fault in the Carrizo Plain occurred in 1857 (Wood, 1955; Agnew and Sieh, 1978), we conclude that the channel sediments were offset 6.6 to $6.9 \mathrm{~m}$ during the 1857 earthquake.

The time of channel incision is more difficult to determine. On the southwest side of the fault, the channels cut colluvium containing charcoal sample PS3-1. This sample was too small to permit measurement of its $\delta^{13} \mathrm{C}$, so the lab assumed a $\delta^{13} \mathrm{C}$ of -25 to calculate a radiocarbon age of $370 \pm 60$ years and a $2 \sigma$ calendric range of A.D. 1440 to 1640 . Of twelve charcoal samples with measureable $\delta^{13} \mathrm{C}$ collected by the authors at the Phelan fan and Bidart fan sites for this study and other studies (Grant and Sieh, 1991, 1992; L. B. Grant, unpublished manuscript), eight are C-4 plants with an averaged $\delta^{13} \mathrm{C}$ value of approximately -12 . Thus $\mathrm{C}-4$ charcoal samples are more common than C-3 samples in this area. If we assume that sample PS3-1 has a $\delta^{13} \mathrm{C}$ value of -12 , the radiocarbon age is increased by 106 years ( $\mathrm{T}$. Jull, personal communication) to $476 \pm 60$ years $\mathrm{BP}$, and the $2 \sigma$ calender range changes to A.D. 1305 to 1623 
(Stuiver and Reimer, 1986). This suggests that the channels cut the colluvium sometime after a date within the age range 1305 to 1623 A.D. and filled prior to faulting, in 1857.

A piece of charcoal (PS3-16) from a gravel layer that may overlie channel $\mathrm{C}$ just above the colluvium in trench 3 yields a radiocarbon date corresponding to a calendar age range of A.D. 1300 to 1440. This data range overlaps the date of sample PS3-1 below it by 135 years, suggesting that the channel began filling between A.D. 1305 and 1440. However, because the charcoal samples are detrital, it is difficult to place upper limits on the times of channel cutting and filling. The sample dates may be older than the beds which contain them, and therefore we favor the broader time range of A.D. 1305 to 1623 .

An aggregate charcoal sample, PS4-101, was collected directly from the burned horizon in the upper channel $\mathrm{C}$ sediments, on the east side of the fault (Fig. 6). This sample's age is $1016 \pm 19$ radiocarbon years B.P., corresponding to a $2 \sigma$ calendar range of A.D. 901 to 1151 (Stuiver and Reimer, 1986). This date is several centuries older than the age of the charcoal from the colluvium into which the channel was incised. Thus, the age of sample PS4-101 probably reflects either the age of a long-lived plant, a long period of time between plant death and sample deposition, or both, rather than the dates of channel filling. Blong and Gillespie (1978) report up to 1500 years difference between the true age of twentieth century river sediments in Australia, and the charcoal contained within them. They attribute the age difference to detrital wood storage in the drainage basin prior to deposition, and a 200 to 300 year life expectancy of local trees.

A single piece of charcoal resembling a twig was selected from the aggregate PS4-101 sample for a second date because we judged the twig would likely be younger than heartwood which might 'contaminate' the aggregate sample. The age of the twig, sample PS4-101t, was younger (600 \pm 50 radiocarbon years B.P.) than sample PS4-101. This corresponds to a $2 \sigma$ calendar range of A.D. 1263 to 1438 , one to several centuries younger than the bulk sample. The $\delta^{13} \mathrm{C}$ of the aggregate sample PS4-101 indicates that it came from C-4 plant material. The woody texture and high $\delta^{13} \mathrm{C}$ value of the charcoal suggests that the plant might be Atriplex polycarpa, or common saltbush (Smith and Epstein, 1971; L. Toolin, personal communication). A. polycarpa is common in the subshrub plant community of the Carrizo Plain, and was more common prior to the introduction of grazing (Hubert and Kakiba-Russell, 1991). It is difficult to estimate the life expectancy of $A$. polycarpa in the Carrizo Plain. It resprouts after fires (E. McMillan, personal communication) and is listed by Barbour and Major (1988) as an "important long-lived species," along with creosote. Thus, it is possible that the difference in ages of samples PS4-101 and PS4-101t represents the approximate lifespan of a saltbush transported to the excavation site by flood waters, burned in situ as detrital wood by a wildfire, and then buried by sediments. If so, the younger date better represents the time of deposition, although it could still be older than the surrounding sediments. Another possibility is that PS4-101 and PS4-101t are from entirely different plants. In that case, the younger date (A.D. 1263 to 1438) still gives a better estimate of the time of deposition than the older date.

From the radiocarbon dates and stratigraphic evidence, we conclude that the channel piercing line was offset 6.6 to $6.9 \mathrm{~m}$ by the 1857 earthquake. The offset channel $\mathrm{C}-\mathrm{C}^{\prime}$ was cut sometime after a date within the range A.D. 1305 to 
1623. The pre-1857 earthquake occurred prior to the channel incision, prior to a date within the range A.D. 1305 to 1623 . It occurred prior to deposition of channel fill containing pieces of detrital charcoal dated at A.D. 1300 to 1440 , 1263 to 1438 , and 901 to 1151 .

\section{Discussion}

One interpretation of our observations is that the larger 9 to $10 \mathrm{~m}$ geomorphic offsets observed near Wallace Creek by Sieh and Jahns (1984) represent slip from two events; 6 to $7 \mathrm{~m}$ in 1857 and 2 to $3 \mathrm{~m}$ in a previous event (Fig. 9). Similar distributions of geomorphic offsets along the Garlock fault have been interpreted as evidence for multiple events (McGill and Sieh, 1991). There is evidence to support a hypothesis of 6 to $7 \mathrm{~m}$ of slip over most of the 1857 rupture length. Lienkaemper and Sturm (1989) argue for $5.7 \mathrm{~m}$ of slip from the 1857 earthquake near Cholame, northwest of Wallace Creek, although they have no stratigraphic evidence to prove that all of the offset occurred in a single event rather than two 3-m slip events, as argued by Sieh and Jahns (1984). Approximately $6 \mathrm{~m}$ of slip is reported by Sieh (1978) and Sieh and Jahns (1984) along the southern half of the Carrizo segment of the San Andreas fault. Salyards et al. (1992) measured approximately $6 \mathrm{~m}$ of slip at Pallett Creek (Fig. 1), where slip was previously thought to be much less (Sieh 1978, 1984). Thus, 6 to $7 \mathrm{~m}$ of slip in 1857 has been reported at sites along nearly the entire length of the 1857 rupture, including the Wallace Creek section. If the maximum slip section of the San Andreas fault reported by Sieh (1978) and Sieh and Jahns (1984) near Wallace Creek actually sustained 6 to $7 \mathrm{~m}$ of slip in 1857, then the peak slip section may have ruptured with 2 to $3 \mathrm{~m}$ of peak slip in a previous event (Fig. 9). Data from other strike-slip earthquakes show that 2 to $3 \mathrm{~m}$ of peak slip is plausible for a $35-\mathrm{km}$ rupture, corresponding to a $M_{s} 7.2$ to 7.3 earthquake (Bonnilla et al., 1984).

Another plausible hypothesis to explain our observations is that the slip varied by several meters over a distance of about $2 \mathrm{~km}$ along strike. Such variation in offsets is not unusual. Dextral offsets from the 1992 Landers earthquake varied several meters in less than a kilometer (Rubin and McGill, 1992). Similar variation has been reported from other strike-slip earthquakes. Slip in the 1940 Imperial Valley earthquake increased from $2 \mathrm{~m}$ to a peak of $6 \mathrm{~m}$ over a distance of approximately $6.5 \mathrm{~km}$, with a $2-\mathrm{m}$ increase occurring over a 2 to $3 \mathrm{~km}$ stretch (Sharp, 1982). Reported slip from the 1968 Dasht-E-Bayaz earthquake in Iran decreased from 3.0 to $1.5 \mathrm{~m}$ within approximately $100 \mathrm{~m}$ along the fault (Ambraseys and Tchalenko, 1969).

It should also be recognized that slip may vary from earthquake to earthquake at a given site. For example, at Phelan Ranch, we report geomorphic offsets of approximately 7 and $21 \mathrm{~m}$ (Fig. 3). At nearby Phelan Creeks (Figure 1), Sims et al. (1989) report an offset of $15.8 \pm 0.6 \mathrm{~m}$. If $7 \mathrm{~m}$ of slip occurred in 1857 at Phelan Creeks, the remaining 8 to $9 \mathrm{~m}$ of offset at Phelan Creeks may be from the prior event. Thus, at Phelan Ranch the last three earthquakes may have produced approximately 7,8 to 9 , and 5 to $6 \mathrm{~m}$ of slip respectively, forming offsets of $7 \mathrm{~m}, 15$ to $16 \mathrm{~m}$, and $21 \mathrm{~m}$. At Wallace Creek, offsets of approximately $9.5,22$, and $33 \mathrm{~m}$ have previously been interpreted as the result of $9.5,12.5$, and $11 \mathrm{~m}$ of slip respectively, from the last three earthquakes. If the gully that is offset $22 \mathrm{~m}$ was formed by three earthquakes rather than by two earthquakes (as hypothesized by Sieh and Jahns (1984)), then the slip at Wallace Creek 


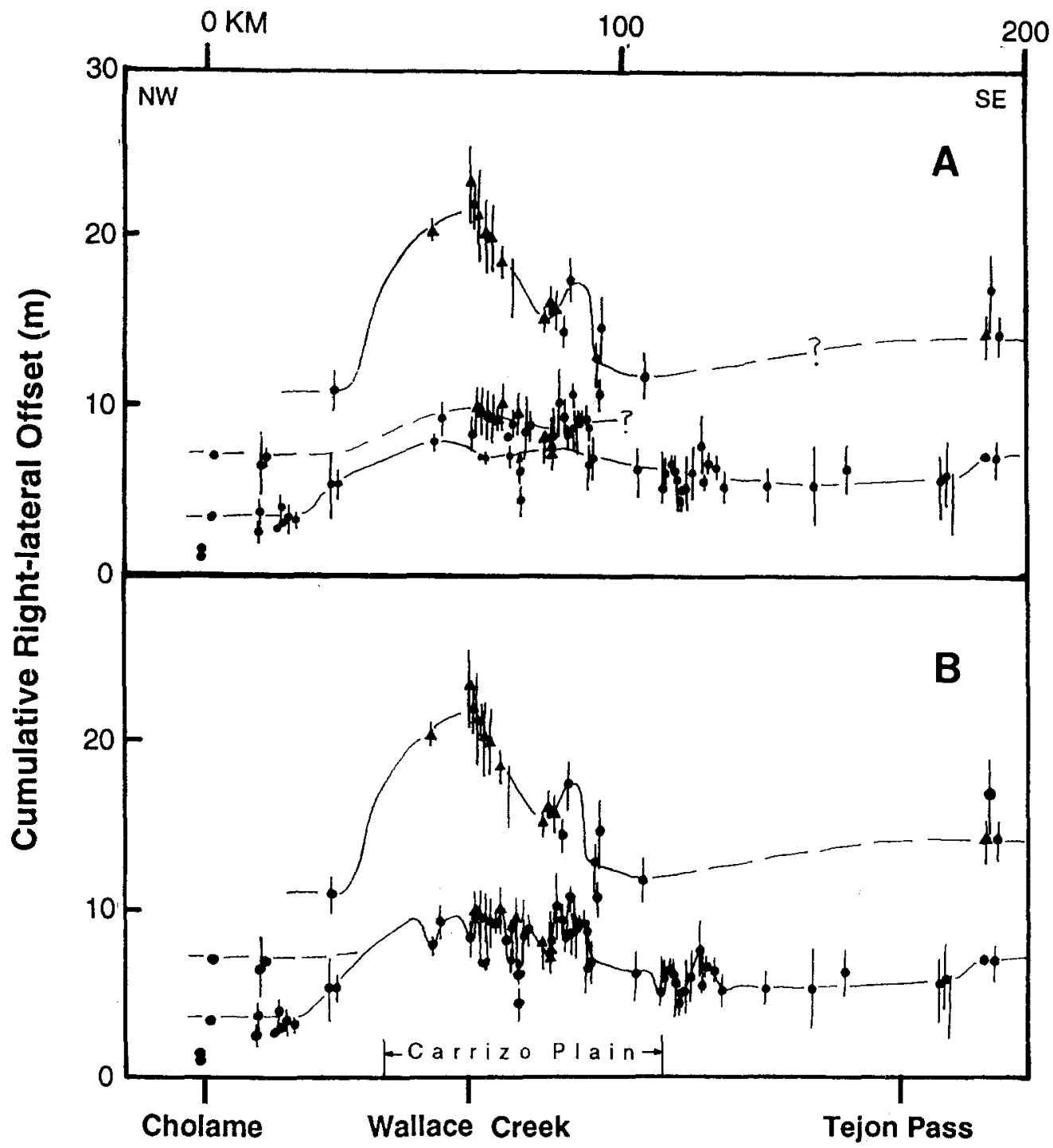

FIG. 9. Measurements of offset geomorphic features versus distances along the south-central section of the San Andreas fault, reported by Sieh and Jahns (1984), show peak values along a 35 $\mathrm{km}$ stretch of the fault in the Carrizo Plain. Each symbol represents an offset measurement, with error bars. New measurements presented in this paper are included. The lines joining the symbols show two possible interpretations of earthquake rupture patterns. Box A indicates 6 to $7 \mathrm{~m}$ of slip near Wallace Creek in 1857, and 2 to $3 \mathrm{~m}$ of rupture in the previous earthquake. Box B shows highly variable $(6$ to $10 \mathrm{~m})$ slip in 1857. Modified from Sieh and Jahns (1984).

might have been a more modest $9.5,6$ to 7 , and 6 to $7 \mathrm{~m}$ during the last three earthquakes. From the geomorphic data alone, there is no reason to favor one interpretation over another because there is no constraint on the number of events which formed each offset.

Slip variation in 1857 along the section of San Andreas fault we have investigated could be related to long-term variation in the amount of slip on the main fault strand. However, if a slip deficit repeatedly occurs at the same place over several earthquake cycles, complementary structures or multiple traces 
would be expected to form, unless deformation was distributed over a very broad area.

The most important implication, and perhaps the only conclusion, that can be drawn from the data presented herein is that, due to substantial uncertainties in their measurement and interpretation, the smallest geomorphic offsets in the Carrizo Plain currently provide only rough constraints on the amount of slip per earthquake. An important consequence is that slip-based hypotheses about earthquake recurrence, the location of fault-segment boundaries, and seismic hazard should not ignore these uncertainities. Conditional earthquake probabilities calculated with the assumption of a time-predictable model of earthquake recurrence must reflect the large uncertainities in interpreting the number of earthquakes attributed to each offset. Preliminary dates of paleoseismic events in the Carrizo Plain suggest irregular recurrence intervals for prehistoric earthquakes on the San Andreas fault (Grant and Sieh, 1992). Therefore, mechanical models of a strong Carrizo fault segment which breaks infrequently and with at least $9 \mathrm{~m}$ of peak slip may be incorrect and should be reconsidered.

\section{ACKNOWLEDGMENTS}

We greatly appreciate the support and access given by land owners Arthur Phelan and Leonard Bidart. We also thank S. Grant, G. Holk, K. Hudnut, L. Maepa, S. McGill, E. Nagy, C. Prentice, J. Ritchie, M. Slates, A. Thomas, T. Wachholz, K. Wiese, and D. Wood for assistance with the field work. J. Mayne helped draft the figures. Most radiocarbon samples were dated at the NSF Accelerator Facility at the University of Arizona and were partially funded by NSF grant EAR85-12761. We thank M. Stuiver at the University of Washington Quaternary Isotope Lab for a high precision radiocarbon date. The University of Toronto IsoTrace lab dated one radiocarbon sample. R. Weldon, S. Wesnousky, S. Grant, and an anonymous reviewer greatly improved the manuscript. Financial support was provided by USGS grant No. 14-08-001-G1789. This is California Institute of Technology, Division of Geological and Planetary Sciences contribution No. 5179.

\section{REFERENCES}

Agnew, D. C., and K. E. Sieh (1978). A documentary study of the felt effects of the great California earthquake of 1857, Bull. Seism. Soc. Am. 68, 1717-1730.

Ambraseys, N. N., and J. S. Tchalenko (1969). The Dasht-e-Bayaz (Iran) earthquake of August 31, 1968: A field report, Bull. Seism. Soc. Am. 59, 1751-1792.

Bakun, W. H., and A. G. Lindh (1985). The Parkfield, California, earthquake prediction experiment, Science 229, 619-624.

Bakun, W. H., and T. V. McEvilly (1984). Recurrence models and Parkfield, California, earthquake, J. Geophys. Res. 89, 3051-3058.

Barbour, M. G., and J. Major, eds. (1988). Terrestrial Vegetation of California, California Native Plant Society, Special Publ. 9, University of California, Davis.

Blong, R. J., and R. Gillespie (1978). Fluvially transported charcoal gives erroneous ${ }^{14} \mathrm{C}$ ages for recent deposits, Nature 271, 739-741.

Bonilla, M. G., R. K. Mark, and J. J. Lienkaemper (1984). Statistical relations among earthquake magnitude, surface rupture length, and surface fault displacement, Bull. Seism. Soc. Am. 74, $2379-2411$.

Grant, L. B., and K. E. Sieh (1991). New data on the timing and slip per event of earthquakes on the San Andreas fault, southern California, EOS 72, 351.

Grant, L. B., and K. E. Sieh (1992). Irregular recurrence times and increased seismic hazard from earthquakes on the Carrizo segment of the San Andreas fault, southern California, in Proc. of the 35th Ann. Meeting of the Assoc. of Engineering Geologists, Los Angeles, California, October $2-9,1992,567-568$.

Huang, J., and D. L. Turcotte (1990). Evidence for chaotic fault interactions in the seismicity of the San Andreas fault and Nankai trough, Nature 348, 234-236.

Hubert, E., and K. Kakiba-Russell (1991). Carrizo Plain Natural Area: A Checklist of Vascular Plants, California Energy Commission. 
Lienkaemper, J. J., and T. A. Sturm (1989). Reconstruction of a channel offset in 1857(?) by the San Andreas fault near Cholame, California, Bull. Seism. Soc. Am. 79, 901-909.

McGill, S. F., and K. E. Sieh (1991). Surficial offsets on the central and eastern Garlock fault associated with prehistoric earthquakes, J. Geophys. Res. 96, 21597-21621.

Nagy, E. A., and K. E. Sieh (1993). The use of paleomagnetic analysis to assess nonbrittle deformation within the San Andreas fault zone, J. Geophys. Res. (in press).

Rubin, C. R., and S. F. MeGill (1992). The June 28, 1992 Landers earthquake: slip distribution and variability along a portion of the Emerson fault, EOS 73, 362.

Rundle, J. B. (1988). A physical model for earthquakes 2. Application to Southern California, $J$. Geophys. Res. 93, 6255-6274.

Salyards, S. L., K. E. Sieh, and J. L. Kirschvink (1992). Paleomagnetic measurement of non-brittle coseismic deformation across the San Andreas fault at Pallett Creek, southern California, $J$. Geophys. Res. 97, 12457-12470.

Scholz, C. H. (1990). Earthquakes as chaos, Nature 348, 197-198.

Schwartz, D. P., and K. J. Coppersmith (1984). Fault behavior and characteristic earthquakes: Examples from the Wasatch and San Andreas fault zones, J. Geophys. Res. 89, 5681-5698.

Sharp, R. V. (1982). Comparison of 1979 surface faulting with earlier displacements in the Imperial Valley, in The Imperial Valley, California Earthquake of October 15, 1979, C. E. Johnson, C. Rojahn and R. V. Sharp U.S. Geol. Surv. Profess. Paper 1254, 213-221.

Sieh, K. E. (1978). Slip along the San Andreas fault associated with the great 1857 earthquake, Bull. Seism. Soc. Am. 68, 1421-1448.

Sieh, K. E. (1984). Lateral offsets and revised dates of large prehistoric earthquakes at Pallett Creek, Southern California, J. Geophys. Res. 89, 7641-7670.

Sieh, K. E., and R. H. Jahns (1984). Holocene activity of the San Andreas fault at Wallace Creek, California, Geol. Soc. Am. Bull. 95, 883-896.

Sieh, K. E., M. Stuiver, and D. Brillinger (1989). A more precise chronology of earthquakes produced by the San Andreas fault in Southern California, J. Geophys. Res. 94, 603-623.

Sims, J. D., T. Ito, J. C. Hamilton, and D. B. Meier (1989). Late Holecene record of earthquakes and slip on the San Andreas fault in excavations on the Carrizo Plain, California, EOS 70, 1349.

Smith, B. N., and S. Epstein (1971). Two categories of ${ }^{13} \mathrm{C} /{ }^{12} \mathrm{C}$ ratios for higher plants, Plant Physiol. 47, 380-384.

Stuart, W. D. (1986). Forecast model for large and great earthquakes in Southern California, $J$. Geophys. Res. 91, 13771-13786.

Stuiver, M., and P. J. Reimer (1986). Computer program CALIB, Radiocarbon 28, 1022-1033.

Sykes, L. R., and S. P. Nishenko (1984). Probabilities of occurrence of large plate rupturing earthquakes for the San Andreas, San Jacinto, and Imperial faults, California, J. Geophys. Res. 89, 5905-5927.

Wesnousky, S. G. (1986). Earthquakes, Quaternary faults, and seismic hazard in California, $J$. Geophys. Res. 91, 12587-12631.

Wood, H. O. (1955). The 1857 earthquake in California, Bull. Seism. Soc. Am. 45, 47-67.

Working Group on California Earthquake Probabilities (1988). Probabilities of large earthquakes occurring in California on the San Andreas fault, U.S. Geol. Surv. Open File Rept. 88-398.

SEISMOLOGICAL LABORATORY 252-21

CALIFORNIA INSTITUTE OF TECHNOLOGY

Pasadena, CA 91125

Manuscript received July 1, 1992 